\title{
Rousseau e Genebra ${ }^{1}$ \\ ROUSSEAU AND GENEVA
}

\section{Christopher Bertram ${ }^{2}$}

\begin{abstract}
RESUMO: Os estudiosos vêm se dividindo acirradamente sobre a relevância da política e da história de Genebra na filosofia política de Rousseau. Eu busco chegar a uma visáo coerente do compromisso de Rousseau com Genebra, uma que rejeita tanto a ideia de que ela é simplesmente irrelevante ao núcleo das doutrinas políticas do autor, quanto a que essencialmente lê tudo como uma intervençấo na política genebrina. Nenhuma dessas concepçôes parece correta. De fato, Genebra, como Rousseau a concebeu, é uma presença constante que informa seu pensamento de modos diferentes. Rousseau não foi tâo ingênuo a ponto de pensar que Genebra encarnava seus princípios, mas também não viu a verdadeira natureza da cidade como uma oligarquia hereditária. Ele a julgou defeituosa, porém remediável, uma avaliação talvez marcada pela aversão ao conflito civil, ao menos até que a realidade genebrina colidisse com suas ilusōes.
\end{abstract}

PALAVRAS-CHAVE: Rousseau. Genebra. Política.

\section{INTRODUÇÁO}

A principal dificuldade em tentar escrever sobre a Genebra de Rousseau é a de estabelecer o que se está tentando escrever a esse respeito. Ou melhor, uma vez que se está tentando escrever sobre várias coisas muito diferentes, ao mesmo tempo, a dificuldade consiste em estabelecer qual é a relação entre essas várias coisas. Podemos enumerar algumas das possibilidades. Em primeiro lugar, há a Genebra da época de Rousseau, tanto como uma sociedade real quanto como uma entidade legal e constitucional. Estas são coisas diferentes uma da outra, pois, tal como se dá com todas as sociedades políticas, o modo como as coisas realmente acontecem pode se aproximar mais ou menos de como elas deveriam acontecer. Essa Genebra não é uma entidade fixa no

\footnotetext{
${ }^{1}$ Tradução de Renato Moscateli. Doutor em Filosofia pela UNICAMP. Professor da Universidade Federal de Goiás e membro do Programa de Pós-Graduação em Filosofia da instituição. E-mail: rmoscateli@hotmail.com - http://dx.doi.org/10.1590/S0101-31732015000400009

${ }^{2}$ Professor de Filosofia Social e Política na University of Bristol. Presidente da Rousseau Association, entre 2007 e 2009. Autor de Rousseau and The Social Contract (Routledge's Philosophy Guidebooks). Pesquisa temas nas áreas da teoria moderna do contrato social, das teorias da justiça (especialmente justiça distributiva global, incluindo questôes relativas a território e migração) e da justificação pública.E-mail: chris.bertram@gmail.com
} 
tempo, visto que ela é marcada por conflitos políticos - às vezes violentos - os quais precedem o nascimento de Rousseau e as mudanças constitucionais que ocorreram durante sua vida, a exemplo da Mediação de 1738 e da "revolução burguesa” de 1768. Em segundo lugar, há a Genebra como foi imaginada pelos cidadãos comuns do lugar e a extensão em que Rousseau compartilhou da perspectiva deles. Possivelmente, muitos dos cidadãos e burgueses do partido mais "democrático" compartilhavam de um conjunto de ilusóes sobre Genebra e sua ordem constitucional, ilusóes que foram evidenciadas após a condenação do Contrato Social pelo Pequeno Conselho. Em terceiro lugar, há as crenças pessoais de Rousseau sobre sua cidade natal, tais como elas se desenvolveram ao longo do tempo. Algumas delas são crenças sobre seu funcionamento político, outras sobre o espírito que a animava e sobre seus cidadãos como modelos de virtude republicana. Em quarto lugar, e finalmente por enquanto, temos Genebra como foi representada nas obras de Rousseau.

Uma hipótese natural, embora ingênua, seria a de que a Genebra que Rousseau retrata em suas obras também mostraria o que eram suas crenças pessoais sobre Genebra, mas há algumas razóes para suspeitar de tal ideia, porque, assim como outros atos de comunicação, os textos de Rousseau são tentativas de fazer algo e, como tentativas de fazer algo - interferir, persuadir, debater etc. -, eles não são o mesmo que uma sequência de afirmaçóes factuais sobre as crenças sinceras do autor. Essa distinção é particularmente acentuada no caso de um texto como a Dedicatória do Discurso sobre a origem da desigualdade, em relação à qual os comentadores se dividem entre os que a leem como uma expressão genuína de elogio à pátria feita por alguém dominado por crenças seriamente equivocadas sobre o que sua pátria realmente era, e os que a entendem como tendo sido escrita ironicamente, como uma intervenção dissimulada e deliberada por alguém que estava perfeitamente consciente de que a autoimagem de Genebra era muito diferente de sua realidade. E também há a questão das fortes reaçóes emocionais que Rousseau ainda provoca em seus leitores, bem como a tensão mais do que ocasional entre o que ele disse ou fez e o que nós gostaríamos que ele tivesse feito e dito. Se estivermos comprometidos com uma visão de Rousseau como alguém sofisticado, inteligente e bem informado, então isso nos levará a sermos mais inclinados a ler um texto como a Dedicatória como uma intervenção disfarçada, em vez de como um erro ingênuo; e se estivermos ligados a uma visão de Rousseau como um inspirador de modelos de autogoverno participativo e da democracia deliberativa, então ficaremos propensos a dar satisfaçóes sobre a omissão aparente de Rousseau acerca da maioria privada de direitos na cidade e de sua 
indisposição a dar ao Conselho Geral, nominalmente soberano, o direito de iniciativa legislativa.

Na sequência, tentarei chegar a um entendimento coerente da ligação de Rousseau com Genebra, um que rejeita tanto a ideia de que Genebra é simplesmente irrelevante para suas doutrinas políticas centrais, quanto a concepção que basicamente lê tudo como uma intervenção política nos assuntos públicos genebrinos. Nenhuma dessas visóes parece correta. De fato, Genebra é uma presença constante que informa seu pensamento de diversas maneiras. Rousseau não era tão ingênuo a ponto de pensar que Genebra encarnava seus princípios, mas também náo via claramente sua verdadeira natureza como uma oligarquia hereditária. Ele julgou-a defeituosa, porém, remediável, um juízo talvez informado por uma aversáo ao conflito civil, pelo menos até que a realidade genebrina colidisse com suas ilusóes.

\section{GENEBRA}

No século XVIII, Genebra era governada de acordo com um conjunto de Éditos originalmente aprovados em 1543, os quais eram, em sua essência, meramente a codificação de práticas herdadas da Idade Média. ${ }^{3}$ Segundo os éditos, o poder em Genebra era distribuído entre quatro corpos: o Conselho Geral, o Conselho dos Duzentos, o Conselho dos Sessenta e o Conselho dos Vinte e Cinco (ou Pequeno Conselho). O Conselho Geral era composto de todos os cidadáos e burgueses da cidade, e os outros conselhos por subconjuntos de cidadãos. O Conselho Geral parece ter desempenhado um papel de destaque no governo da cidade sob o regime episcopal, mas muito menos sob a república, e os poderes que ele tinha - tal como o de aumentar os impostos -, transferiu-os bastante cedo para os outros corpos. Daí em diante, ele se reunia, embora dificilmente ocorresse, como um tipo de corpo consultivo quando o Pequeno Conselho, o verdadeiro órgáo governante de Genebra, estava dividido ou de algum modo incapaz de tomar uma decisão. Em suma, ele era essencialmente

\footnotetext{
${ }^{3}$ Embora Rousseau às vezes represente Calvino como um grande Legislador, ele somente foi isso no próprio sentido rousseauniano de conceder um espírito animador à cidade, pois ele parece ter sido pouco mais do que um membro de um comitê de elaboração.
} 
um corpo consultivo, apesar de manter o poder de eleger os quatro Síndicos que dirigiam a república, mas sempre a partir das listas submetidas pelo Pequeno Conselho. ${ }^{4}$

Genebra era também uma sociedade de classes. Isto é verdade tanto no sentido de que sua população era dividida em grupos oficiais de status quanto em um sentido sociológico mais convencional. Da população de cerca de 25.000 pessoas, não mais de $6 \%$ desfrutavam de direitos políticos: tais eram os cidadãos e os burgueses, dos quais apenas os primeiros, nativos cujos pais eram eles próprios cidadáos, podiam ser eleitos para cargos públicos. Os restantes - a vasta maioria, portanto -, conhecidos como os natifs, habitants e sujets, não podiam. Todavia, mesmo dentro do grupo que gozava de direitos políticos, havia uma divisão entre uma elite patrícia rica, composta pelas famílias abastadas geralmente de origem aristocrática francesa ou italiana (e que, em alguns casos, usavam títulos aristocráticos), e os demais. Essa divisão também encontrou uma expressão espacial, na medida em que a elite vivia na parte alta da cidade e os cidadáos mais comuns e os burgueses - coletivamente conhecidos como a bourgeoisie - moravam no bairro de St. Gervais. Essa elite patrícia dominava e governava por meio do Pequeno Conselho e de sua participação nos dois conselhos intermediários.

Esse sistema ficou sob pressão por volta do final do século XVII devido a duas razóes, uma econômica e outra ideológica. A razão econômica foi que a burguesia ofendeu-se com várias medidas do Pequeno Conselho, as quais incluíam dar alguns direitos comerciais a refugiados franceses e agir em detrimento dos genebrinos que tinham vinhedos fora do território. A razão ideológica era a circulação de ideias vindas da Inglaterra, em particular as encontradas no Segundo Tratado do Governo de Locke. A indignação das classes comerciais quanto a um Estado que deveria ser mais responsável por elas eventualmente irrompeu em conflito aberto em três ocasióes distintas: 1707, 1734-8 e, finalmente, 1768. $\mathrm{O}$ primeiro desses conflitos aconteceu antes do nascimento de Rousseau, o segundo ele testemunhou durante uma visita a Genebra, em 1737, para tratar de negócios familiares, e o terceiro pode ter ocorrido, em parte, por causa das controvérsias que se seguiram à condenação do Contrato Social, mas depois que ele já tinha perdido muito do seu interesse pela cidade natal.

Os problemas de 1707 envolveram Pierre Fatio e se seguiram à recusa do Pequeno Conselho diante de uma tentativa de promover várias medidas

\footnotetext{
${ }^{4}$ Eu extraí a descrição histórica da evolução de Genebra de Spink, 1934, capítulos 1 e 2.
} 
democráticas, incluindo a proposta do próprio Fatio a favor de assembleias anuais do Conselho General para "estabelecer e mudar as leis e os éditos". O Pequeno Conselho consentiu com diversas reformas, incluindo uma assembleia periódica quinquenal do Conselho Geral. Entretanto, apoiado por tropas de Zurique e Berna, e a despeito de uma suposta anistia, o Pequeno Conselho prendeu os líderes do partido popular e executou Fatio, de maneira que a primeira das assembleias quinquenais do Conselho Geral confirmou a rejeição da reivindicaçáo por assembleias periódicas. Seguiu-se um período de relativa calma, durante o qual as facçóes opostas e mutuamente receosas vieram a formular suas teorias políticas mais precisamente. A facção burguesa assumiu a visão de que, como o Conselho Geral tinha o título de "soberano", ele possuía, portanto, o direito de ser o poder supremo no Estado, embora a facção não fosse absolutamente clara sobre se essa autoridade era baseada em um princípio de soberania popular ou se era simplesmente uma consequência do fato de esse corpo ter herdado os poderes deixados pela partida do bispo, em 1533. O partido patrício formulou uma doutrina de acordo com a qual os vários conselhos eram "ordens" coiguais no Estado, segundo uma teoria da separaçáo dos poderes semelhante à de Montesquieu, sem que qualquer corpo singular fosse supremo e nenhum sendo autorizado a modificar o equilíbrio constitucional unilateralmente. Essa é, essencialmente, a doutrina defendida mais tarde por Tronchin, nas Cartas escritas do campo e atacada por Rousseau nas Cartas escritas da montanha.

Após as representaçóes sobre o tema da taxação, em 1734, o partido patrício, preocupado com o poder da facção burguesa, mobilizou-se para assegurar o desarmamento dela, uma medida contra a qual houve resistências bem-sucedidas. Contudo, uma segunda tentativa, durante a qual os patrícios foram auxiliados pelos "nativos" que eles haviam subornado, levou ao conflito aberto em 1737 e à eventual "mediação" da França, de Berna e de Zurique. O Édito de Mediação de 1738 definiu os poderes dos vários corpos e estava constitucionalmente em funcionamento na época em que Rousseau escreveu a Dedicatória, quando ele reivindicou sua cidadania, em 1754, quando escreveu a Carta a d'Alembert e, principalmente, no momento da publicação do Contrato Social. O Édito de Mediação aplicou e reforçou a interpretação dos patrícios sobre a constituição genebrina, mas o fez ao mesmo tempo em que supostamente reconhecia o Conselho Geral como o "Conselho Soberano" e se referia a ele como possuindo poderes legislativos, eletivos e confederativos, os quais, na verdade, eram-lhe negados pelos detalhes práticos do documento. Ao Conselho Geral foi explicitamente negado o direito de iniciativa legislativa: 
ele podia votar apenas nos candidatos propostos pelo Pequeno Conselho e, embora a burguesia mantivesse o direito de fazer representaçóes contra açóes do Pequeno Conselho, ela perdeu o direito de se reunir por regimentos em apoio a essas representaçóes e, desse modo, a habilidade de criar uma ameaça efetiva contra o poder patrício. Além disso, o Pequeno Conselho reservou para si o direito de decidir o que fazer com as representaçóes e, sobretudo, o de expô-las ou não diante do Conselho Geral. Na prática, portanto, o direito de fazer representaçóes não chegava a ser muito mais do que um direito de entregar petiçóes ao governo.

\section{ROUSSEAU}

Como é bem conhecido, embora Rousseau tivesse sido educado como um genebrino patriota por seu pai - um fato celebremente relembrado na cena da dança do regimento, na Carta a d'Alembert -, ele abandonou a cidade aos dezesseis anos, em 1728, e, devido à sua conversão ao catolicismo, perdeu todos os seus direitos de cidadania. Fez uma rápida visita à cidade, em 1737, contudo, esse foi o único período que passou lá, entre 1728 e 1754. Imediatamente antes disso, em 1754, ele compôs a famosa Dedicatória, a qual elogia, ou parece elogiar o sistema de governo genebrino. Após 1754, Genebra ganha proeminência em seus escritos durante dois episódios. O primeiro é sua réplica, em 1758, ao artigo de d'Alembert sobre Genebra na Enciclopédia, e o segundo são as Cartas escritas da montanha, de 1764, nas quais ele responde a Tronchin. A isso nós podemos acrescentar o próprio Contrato Social, o qual Rousseau afirmou, nas Cartas escritas da montanha, ser uma defesa dos princípios básicos da constituição genebrina. Essa obra também inclui uma referência direta às ordens de status de Genebra em uma nota de rodapé do capítulo sobre o pacto social e, como algo passível de discussáo, contém prescriçóes para o governo, tais como as assembleias periódicas do povo e a iniciativa legislativa pelos magistrados, as quais ecoam os ordenamentos de Genebra ou as aspirações dos protagonistas genebrinos.

O Contrato Social foi condenado pelo Pequeno Conselho em Genebra e queimado, o que parece ter sido completamente chocante para Rousseau. As autoridades genebrinas escolheram bem os fundamentos para a condenação, uma vez que elas atacaram a heterodoxia religiosa do capítulo sobre a religião civil, o que era uma forma eficaz de desacreditar Rousseau como sendo menos do que propriamente um cristâo aos olhos dos genebrinos comuns. Isso explica 
parcialmente por que ele recebeu tâo pouco apoio dentro de Genebra, num primeiro momento. Rousseau tentou recuperar sua reputação como um cristão com a Carta a Christophe de Beaumont, mas esta também foi condenada. A reação de Rousseau foi renunciar à sua cidadania com desgosto. Apenas depois dessa renúncia, estimulado por membros da burguesia genebrina horrorizados com o tratamento que ele recebeu, foi que Rousseau realmente se engajou em uma polêmica aberta com os representantes oficiais do partido patrício e redigiu as Cartas escritas da montanha.

\section{Diferentes escolas de Pensamento SObre a RelaÇáo Rousseau-GenEbra}

Uma importante questão interpretativa é até que ponto Rousseau foi influenciado, na formulação de suas principais doutrinas normativas, pelo exemplo da república genebrina. Os textos-chave aqui são a Dedicatória e o Contrato Social. As Cartas escritas da montanha, embora tenham claramente alguma relevância a esse respeito, não podem nos ajudar a estabelecer a relação diretamente, pois Rousseau já tinha formulado suas principais doutrinas na época em que elas foram compostas. As Cartas podem conter afirmaçóes acerca da visão de Rousseau sobre a relaçáo entre seus princípios e Genebra, mas não podemos ter sempre certeza de que elas não são racionalizações post hoc em vez de evidências genuínas de influência causal.

Há três escolas de pensamento principais sobre a relação entre Genebra e a teoria política da Dedicatória e do Contrato Social. Nós podemos chamar a primeira delas de a tese "ingênua e ignorante", a qual é atribuível a John Stephenson Spink e Robert Derathé. ${ }^{5}$ Ela sustenta que, na época de composição dessas obras, Rousseau era basicamente ignorante da real constituição de Genebra e, por isso, qualquer ideia de que as obras refletem ou são inspiradas pelo exemplo genebrino deve ser rejeitada. Rousseau pode ter nutrido uma imagem rósea de sua pátria de infância, uma imagem que encontra expressão tanto na prosa floreada da Dedicatória quanto no choque e na surpresa de Rousseau diante da resposta genebrina ao Contrato Social, todavia, a esse respeito, a real inspiração para suas doutrinas está em outro lugar, especialmente na tradiçáo do pensamento político e na teoria do direito natural. A segunda visão, que encontramos expressa de vários modos diferentes por autores como Michel Launay, Helena Rosenblatt, Blaise Bachofen e, discutivelmente, James

${ }^{5}$ SPINK (1934); DERATHÉ (1995). 
Miller, ${ }^{6}$ nós podemos denominar como a tese da "polêmica oculta". De acordo com essa visão, Rousseau conhecia perfeitamente bem a verdadeira natureza oligárquica da constituição de Genebra, desaprovava-a e realmente endossava a política do partido popular em grande medida. Portanto, o elogio a Genebra encontrado na Dedicatória náo deve ser lido como a expressão da concepção ponderada de Rousseau sobre a realidade de Genebra, mas, de fato, como um tipo de polêmica sofisticada que seria entendida pelos que "estavam por dentro" como uma crítica direta à oligarquia. Nessa perspectiva, o elogio de Rousseau a Genebra é parecido com o elogio de Marco Antônio a Brutus - e, semelhantemente, ninguém é enganado por ele. ${ }^{7}$ A terceira visão, discutida por Richard Fralin, ${ }^{8}$ é a de que as instituiçôes genebrinas foram de fato influentes na formação das concepçóes de Rousseau e que nós deveríamos reler alguns de seus aspectos mais conservadores nas doutrinas centrais dele. Podemos chamar essa terceira visão de tese "conservadora tácita". Segundo ela, deveríamos também reduzir a tensão entre a Genebra real e o "governo democrático sabiamente temperado", porém, dessa vez, questionando o compromisso de Rousseau com os ideais democráticos. Tanto na visão "polêmica oculta" quanto na "conservadora tácita", deveríamos considerar a atitude de Rousseau como algo menos do que completamente sincera: ou ele náo é o entusiasta de Genebra que pretende ser, ou seu compromisso com a soberania popular, em obras como o Contrato Social, é mais questionável do que parece, na superfície.

Todas essas concepçóes têm alguns argumentos poderosos a seu favor e, quando vamos além do modo polêmico como seus autores às vezes escreveram uns sobre os outros, na verdade, elas sáo menos mutuamente contraditórias do que poderiam parecer. Spink, por exemplo, não tem problemas para demonstrar a discrepância entre o que Rousseau professa e a constituição genebrina, por meio de uma exegese detalhada da história constitucional de Genebra. Essa discrepância entre a realidade e a ilusão prossegue até mesmo depois do momento em que Rousseau compreende a natureza do ordenamento político, uma vez que ele continua a confortar a si próprio com a ideia de que o que aconteceu foi uma subversão gradual e imperceptível da soberania popular pela oligarquia genebrina. A dinâmica de tal processo de subversão é brilhantemente analisada por Rousseau, no início da sétima das Cartas escritas da montanha, mas ele pressupóe, nesse ponto, que o Conselho Geral era genuinamente soberano num

${ }^{6}$ LAUNAY (1971); ROSENBLATT (1997); BACHOFEN (2002); MILLER (1984).

${ }^{7}$ A discussão de Miller sobre a Dedicatória pode não parecer se adequar ao padrão, mas ele certamente examina a "crítica codificada" em Miller (1984, p. 68-69).

${ }^{8}$ FRALIN (1978). 
passado muito recente, e Spink não tem dificuldades para mostrar que ele não era. No entanto, essa demonstração do erro de Rousseau é um tanto incompleta por causa da natureza ferozmente debatida da constituição de Genebra. Spink pode evidenciar que a lei e os precedentes favoreciam o partido patrício, mas ele também admite que muitas pessoas no partido popular compartilhavam de um entendimento defeituoso da constituição, um entendimento no qual as novas doutrinas liberais sobre a soberania popular eram mescladas incoerentemente com crenças acerca da história genebrina. Assim como atualmente nós poderíamos fazer distinçóes entre a constituição dos Estados Unidos como ela seria compreendida por um jurista constitucional, o funcionamento real do sistema político americano e os padróes de crença amplamente compartilhados nos subgrupos políticos (tal como o "Tea Party") sobre a constituição e o sistema dos EUA, igualmente, há margem para aceitar que, na época de Rousseau, uma parcela da população podia manter - e regularmente ratificar para outra - uma visão do funcionamento de Genebra que era, em vários aspectos, uma questão de autoilusão.

Isso significa que um tipo de argumento anti-Spink, grosso modo, um argumento de incredulidade, é mal-orientado e desnecessário. Apoiando-se no trabalho de Michel Launay, Blaise Bachofen objeta que Rousseau deve ter sido consciente a propósito da natureza de classe da sociedade genebrina, da exclusão da vasta maioria da população dos direitos políticos e do fato de que a Mediação de 1738 realmente apenas deu ao Conselho Geral um papel consultivo, em vez de um verdadeiro direito de soberania. Ele levanta a questão adicional de que Rousseau foi uma testemunha dos eventos sangrentos de 1737 e afirma que nenhum dos comentadores que são céticos a respeito do conhecimento de Rousseau sobre a realidade política de Genebra menciona o fato. Sem dúvida, o argumento continua, é inacreditável que Rousseau, um garoto inteligente, educado como um cidadão patriota e, portanto, consciente das diferenças de condição e de privilégios entre ele e seus colegas, teria sido ignorante quanto à realidade política e, desse modo, a experiência de 1737 deve confirmar para nós a visão de que o conhecimento é mais provável do que a ignorância.

É sempre perigoso discutir partindo do argumento de que uma pessoa inteligente deveria ter conhecido um conjunto de fatos, dada a disponibilidade da informação relevante, até chegar à conclusão de que ela realmente os conhecia, e isso parece problemático neste caso. Com certeza, Rousseau estava consciente da exclusáo da maioria da população genebrina dos direitos políticos, contudo, 
se ele estava, isso não parece tê-lo incomodado, infelizmente. A afirmação de que ele deve ter sabido que a Mediação não conferia uma soberania genuína, no sentido de poder supremo, também é problemática à luz do fato de que muitos dos cidadáos e burgueses parecem ter-se contentado com a declaração oficial de que o Conselho Geral permaneceu soberano. Se eles continuavam a relatar uns para os outros essa ficção - que sempre foi uma ficção -, por que Rousseau não poderia tê-la compartilhado?? Ademais, é incorreto sustentar que todos os comentadores céticos fazem silêncio sobre a visita de Rousseau, em 1737, tal como foi registrada nas Confissóes. Spink não somente menciona isso, mas também levanta a questão de que a passagem-chave das Confissóes, na qual Rousseau descreve seu horror diante de pai e filho estando em lados opostos da barricada, foi originalmente composta para o primeiro esboço das Cartas escritas da montanha, em 1764. As cartas de Rousseau que realmente são contemporâneas aos eventos de 1737 mostram muito menos interesse nos assuntos políticos do que se poderia esperar. Launay, Bachofen e outros podem demonstrar plausivelmente um conhecimento geral da política e da sociedade de Genebra pelo autor da Dedicatória e do Contrato Social, porém, não é de um conhecimento dos fatos que Spink e Derathé consideram que ele fosse ignorante.

Dessa forma, a tese de Spink parece muito forte, pois o tipo geral de conhecimento que Rousseau tinha da sociedade genebrina claramente se introduziu em seus escritos, antes de 1764, tanto em termos de detalhes quanto em seus escritos gerais sobre o governo. Um exemplo específico é sua visão sobre a iniciativa legislativa. $\mathrm{Na}$ Dedicatória, ele escreve: "[...] para deter os projetos interessados e mal concebidos, e as inovaçóes perigosas que finalmente arruinaram os atenienses, eu desejaria que cada um náo tivesse o poder de propor novas leis a seu bel prazer; que esse direito pertencesse apenas aos magistrados" (ROUSSEAU, 2003, p. 114). Isto, obviamente, antecipa a passagem no Contrato Social (livro 4, capítulo 1, sétimo parágrafo), onde ele escreveu sobre "[...] o direito de opinar, de propor, de dividir, de discutir, o qual o governo sempre tem o cuidado de reservar apenas aos seus membros". Curiosamente, essa é uma posição que ele mantém nas Cartas escritas da montanha e é um exemplo de que Rousseau, mesmo em face da rejeição das autoridades genebrinas, está relutante em abraçar as maiores demandas do

\footnotetext{
${ }^{9}$ Claramente, alguns genebrinos, tais como Micheli du Crest, rejeitaram a Mediação como a impostura que ela era, mas pode ter sido a eles que Rousseau está se referindo, na Dedicatória, quando escreve sobre "[...] a importunaçấo dos animais barulhentos que continuamente perturbam a tranquilidade pública” (2003, p. 117).
} 
partido popular. Outro claro exemplo da influência de Genebra, no qual dessa vez ele assume a linha mais radical, é seu apoio às assembleias periódicas, uma demanda central dos insurgentes de 1707. Como ele salienta: "[...] deve haver assembleias fixas e periódicas que nada pode abolir ou adiar, de modo que no dia marcado o povo seja legitimamente convocado pela lei, sem que seja preciso para isso qualquer outra convocação formal" (ROUSSEAU, 2003, p. $426)^{10}$. Contudo, mesmo nesse caso, ele resiste à ideia de que o próprio povo poderia tomar a iniciativa e se reunir sem a permissáo dos magistrados.

\section{Genebra na Dedicatória e no Contrato Soctal}

No nível temático mais geral e doutrinal, Gabriella Silvestrini argumenta que, desde o primeiro momento em que Rousseau buscou ligar Genebra a seu pensamento sobre instituiçôes políticas, ${ }^{11}$ ele escolheu enfatizar dois elementos: o primeiro deles é a soberania popular e o segundo é que a forma ideal de governo consiste na da aristocracia eletiva. A soberania popular é explicitamente defendida por Rousseau, na Dedicatória, quando ele escreve ser necessário que "[...] o povo e o soberano sejam a mesma pessoa" e que "Eu teria desejado nascer sob um governo democrático sabiamente temperado" (ROUSSEAU, 2003, p. 112). A aristocracia eletiva é mencionada quando ele escreve sobre o modo como Genebra combina a "[...] igualdade que a natureza colocou entre os homens e a desigualdade que eles instituíram” (2003, p. 111). No Contrato Social, Silvestrini sugere que deveríamos considerar algumas das referências a Veneza como referências tácitas à política de Genebra. Assim, por exemplo, no capítulo do livro 3, sobre a aristocracia como uma forma de governo, Rousseau descreve a aristocracia hereditária como a pior de todas as formas de governo e a aristocracia eletiva como a melhor, mas ressalta, em uma nota de rodapé, que se o método de eleição dos magistrados não for devidamente submetido à lei desejada pelo soberano, haverá uma transformação inevitável de uma forma na outra. Essa degeneração aconteceu em Veneza e, conforme Rousseau afirma, só foi evitada em Berna por causa da extrema sabedoria de seu senado (2003, p. 406-407). O elo retórico entre Veneza e Genebra torna-se explícito no capítulo do livro 4, que trata das eleiçôes, no qual Rousseau chama a atenção para as similaridades estruturais entre as duas cidades, deplora o fato de multidôes de cidadãos comuns de Veneza não terem

\footnotetext{
${ }^{10}$ Contrato Social, livro 3, capítulo 13, primeiro parágrafo.

${ }^{11}$ SILVESTRINI (2005).
} 
chances de chegar às magistraturas; nota que, na verdade, em Veneza, "[...] a nobreza é o próprio povo", acrescentando que, não obstante, seu grande Conselho é tão numeroso quanto o Conselho Geral em Genebra. Todavia, evidentemente, o Conselho Geral em Genebra não tinha mais poder do que a instituição correspondente em Veneza: é difícil evitar a conclusão de que Rousseau está argumentando sobre a relação entre o governo e os cidadãos em Genebra, por meio de uma alusão enquanto evitava a exposição clara e aberta. Se há uma base para essa hipótese de Veneza-como-Genebra, outros capítulos do Contrato Social reforçam o padrão. Em particular, o capítulo 10 do livro 3, "Sobre o abuso do governo e sua tendência a degenerar", pode ser lido como se fosse um alerta acerca do futuro possível de Genebra, na medida em que Veneza exemplifica a tendência natural dos magistrados de usurpar o papel que compete ao povo. Nesses trechos, Veneza não é um código para a realidade de Genebra, mas, na verdade, a sugestão é que Genebra está no limite da legitimidade e que, se a tendência presente continuar, o soberano será usurpado por uma aristocracia hereditária.

\section{As CARTAS ESCRITAS DA MONTANHA}

A surpresa de Rousseau quando da condenação do Contrato Social pelo governo de Genebra parece ter sido genuína, e isso dá algum apoio à ideia de que ele permanecia iludido sobre a verdadeira natureza da oligarquia. $\mathrm{Na}$ sexta das Cartas escritas da montanha, ele se expressa indignadamente diante da reaçáo oficial, queixando-se de que tudo o que ele fez foi representar a própria história de Genebra e nos termos mais amplamente lisonjeiros:

\footnotetext{
E de fato, esse contrato primitivo, essa essência da soberania, esse império das leis, essa instituição do governo, essa maneira de concentrá-lo em diversos graus para compensar a autoridade pela força, essa tendência à usurpaçáo, essas assembleias periódicas, essa habilidade em suprimi-las, essa destruiçáo próxima, enfim, que vos ameaça e que eu gostaria de prevenir; não é essa, traço por traço, a imagem de vossa república, desde seu nascimento até hoje? (ROUSSEAU, 2003, p. 809).
}

Quando Rousseau passa a responder aos argumentos de Tronchin, é notável que ele náo defenda algo parecido com a implementação dos princípios do Contrato Social, em Genebra. Na verdade, ele se engaja em uma polêmica inflexível contra a oligarquia, todavia, não faz isso com base em um radicalismo 
democrático extremo de qualquer tipo, porém, de fato, situando a si mesmo no terreno do Édito de Mediação de 1738 (o Regulamento) e tergiversando sobre seus detalhes e sua interpretação. $\mathrm{O}$ argumento específico no centro de sua polêmica refere-se ao direito de representação e ao direito negativo empregado pelo Pequeno Conselho para anular as representaçôes feitas. Neste ponto, a questão é se os cidadãos podem expressar suas preocupaçóes sobre a violação das leis pelo governo e ter essas queixas submetidas à decisão final do povo. Tronchin argumentara que uma grande quantidade de representaçóes sobre assuntos triviais ameaçaria paralisar o governo e transformar Genebra em uma anarquia; a resposta de Rousseau foi apontar que, se o Pequeno Conselho tivesse o direito de simplesmente recusar tais petiçóes, ele acabaria sendo juiz e júri em causa própria, e que isso não podia ter sido a intenção dos autores do Regulamento. ${ }^{12}$ Embora Rousseau defenda consistentemente uma concepção de acordo com a qual o Conselho Geral (e, portanto, o corpo dos cidadãos) permanece soberano, contra qualquer interpretaçáo deste como apenas um dos componentes de uma separação dos poderes, ele adere à negação da iniciativa legislativa e, desse modo, deixa todas as questôes de definição de agenda nas máos da oligarquia. Sua resposta, por conseguinte, pode ter sido mais radical do que o patriarcado estava disposto a tolerar, mas permaneceu firmemente dentro dos limites da opiniáo burguesa moderada.

\section{UMA LACUNA EMBARAÇOSA}

Uma questáo final que merece alguma atenção em qualquer tratamento desse tópico é a atitude de Rousseau quanto à maioria da população genebrina. Afinal de contas, se você afirma que o povo e o soberano deveriam ser a mesma pessoa, como Rousseau faz, na Dedicatória, parece arbitrário excluir da participação integral no Estado uma boa parcela da população regularmente ativa. Infelizmente, essa é uma questão à qual Rousseau nunca se dirige diretamente, a menos que nós tomemos o exemplo negativo da exclusão que ele faz das mulheres, em relaçáo à cidadania, como sendo um exemplo de que ele lidou com o assunto. ${ }^{13} \mathrm{O}$ mais próximo que ele chega de abordá-lo no Contrato Social é em uma nota de rodapé no capítulo sobre o pacto social, no qual ele observa - no contexto da argumentação de que os cidadãos associados fazem uma cidade no verdadeiro sentido - que d'Alembert, em seu artigo da

\footnotetext{
${ }^{12}$ Sobre isso, ver, por exemplo, o comentário de Spector (2005).

${ }^{13}$ Curiosamente, a república corsa que Rousseau admirava admitia as mulheres na cidadania.
} 
Enciclopédia, distinguiu corretamente as várias ordens de pessoas no Estado genebrino. A isto poderia ser adicionada, no máximo, a passagem no capítulo 15 do livro 2, na qual Rousseau examina a ideia de que a liberdade política na Grécia Antiga poderia ter dependido da escravidão. Em sua História do governo de Genebra, Rousseau lembra que, em seus primeiros anos, não havia distinção em Genebra entre cidadãos e burgueses, e que os filhos dos habitants se tornavam bourgeois em razão de seu nascimento. ${ }^{14}$ Isso é consistente com sua visão de que a história de Genebra é uma longa progressão, partindo da genuína soberania popular até sua extinção, mas ele não expressa uma opinião na obra sobre se esse ius soli à cidadania era justificado, contudo, meramente registra a sua existência. O silêncio de Rousseau sobre esse tópico é claramente um embaraço: dificilmente ele parece consistente com suas concepçóes gerais sobre a liberdade e a autoridade legítima, uma vez que isso tornaria a maioria da população sujeita a leis que ela não escolheu para si.

\section{Rumo A ALGUMAS CONCLUSÓES}

Como combinar esses vários pontos e vertentes em uma concepção mais ou menos coerente acerca das relaçóes entre o pensamento de Rousseau e a realidade genebrina? Duas distinçôes podem ser úteis. A primeira é entre teoria ideal e não ideal. Essa distinção, em alguma medida inspirada por Rousseau, é famosa atualmente por causa do uso que John Rawls fez dela. Por um lado, temos um conjunto de princípios ideais que são, todavia, moderados por um conhecimento dos limites da natureza humana, uma concepção da assim chamada "utopia realista"; por outro, temos uma preocupaçáo pelo que a justiça exige em sociedades que estão realmente muito longe do melhor que elas poderiam ser. Esta é a questão da "teoria não ideal". Essa primeira distinção é entre dois modos de pensar que estão dentro da província do teórico ou filósofo, simplesmente quando aplicados a assuntos diferentes. A segunda distinção é entre escrever como um filósofo com uma preocupação com a verdade, embora verdades sobre objetos diferentes (ideais ou não ideais), e escrever como um ativista ou um político. $\mathrm{O}$ trabalho do filósofo político é descobrir a verdade; o trabalho do político é realizar mudanças. Às vezes, dizer a verdade sobre o que a justiça exige distancia-se do que deveria estar em um manifesto partidário e, se nós insistimos, de modo purista, que nosso

${ }^{14}$ Ver Rousseau (1995, p. 511). 
manifesto expóe a verdade, então condenamos nosso partido à derrota, porque as pessoas não estão prontas para receber a verdade sem rodeios.

As doutrinas centrais de Rousseau sobre a soberania e o governo no Contrato Social e em outros escritos encaixam-se melhor, eu acredito, no domínio da teoria ideal. Isso não significa que elas não se relacionem à experiência histórica e pessoal, e, na verdade, ao próprio entendimento de Rousseau sobre sua herança genebrina. Talvez seja verdade, ocasionalmente, como uma questão de biografia e causalidade, que Rousseau não teria chegado a essas ideias, da forma como as elaborou, se não fosse pelo contexto histórico e pela educação que ele teve. No entanto, suas doutrinas, em grande medida, sustentam-se ou caem por seus próprios méritos, como ideias. Por outro lado, o Contrato Social também inclui elementos importantes de teoria não ideal, principalmente com relação às transiçóes entre diferentes estados sociais e à preservação do Estado contra sua triste e inevitável degeneração. O capítulo sobre o Legislador, a discussão sobre a religiấo civil e muito da exposição de Rousseau acerca de como o governo tende a agir contra o soberano e, finalmente, a subverter o Estado, caem nessa categoria.

Outros escritos de Rousseau têm mais diretamente o caráter de intervenções políticas. As Cartas escritas da montanha são um claro exemplo disso e, talvez, a Carta a d'Alembert também se encaixe nessa categoria. Nessas obras, Rousseau está tentando fazer algo bastante imediato, em vez de apresentar princípios para todos os tempos ou mesmo princípios gerais que adaptam princípios atemporais a circunstâncias não ideais.

Porém, quase inevitavelmente, e como ocorre com qualquer escritor, há confluências entre essas categorias e registros, assim como outras consideraçóes (incluindo as de temperamento psicológico). E não somente confluências, pois os princípios ideais e os não ideais necessariamente se ligam ao que deveríamos fazer em política, e a realidade política também pode lançar correçóes a nossos princípios dando-nos uma vívida demonstração dos modos pelos quais eles falham na prática. Um exemplo notável disso consiste na concepção de Rousseau sobre a relação entre soberano e governo e em sua atitude quanto à separação dos poderes. No Contrato Social, o quadro é relativamente claro: o povo soberano lida com o geral e o universal, por meio das leis desejadas pela vontade geral, e as aplicaçôes particulares delas são o trabalho da aristocracia eletiva composta pelos magistrados. Rousseau não examina o fato de que tratar de particularidades envolve duas funçôes distintas: de um lado, a tarefa executiva de aplicar as leis; de outro, a tarefa judiciária de julgar se a 
lei foi corretamente aplicada. Em Genebra, acontecia que ambas as funçóes estavam nas mãos do Pequeno Conselho, ao menos em algumas questóes, e assim, caso os cidadãos pensassem que os magistrados estavam ultrapassando o que a lei permitia, eles podiam fazer representaçóes para o mesmo corpo suspeito de abusos, o qual entâo se considerava livre para julgar as queixas como infundadas. Nas Cartas escritas da montanha, Rousseau vê claramente tal problema e, sem dúvida, uma reelaboração do Contrato Social teria que levá-lo em conta. De fato, na medida em que Rousseau considerou posteriormente propostas institucionais concretas, em 1768, ele parece ter sido favorável ao uso do Conselho dos Duzentos como um tipo de corte constitucional, um movimento que o teria levado na direção de uma separação dos poderes semelhante à de Montesquieu.

Logo, Genebra é importante, de todas as formas, para o pensamento de Rousseau. Entretanto, para reiterar um ponto que já levantei, a Genebra que anima o pensamento de Rousseau nem sempre é a Genebra da realidade, mas, em vez disso, a Genebra que ele imaginou. Assim, Spink estava correto ao afirmar que Genebra, tal como existia, não era um modelo adequado para o pensamento de Rousseau. Na verdade, Rousseau aceitou um mito sobre a realidade genebrina que era amplamente compartilhado pelos burgueses, um mito envolvendo um tipo de sonho sobre a soberania popular, o qual foi progressivamente erodido pelos magistrados. Ele escolheu situar a cidade não onde ela realmente estava (uma oligarquia hereditária), mas, antes, como estando no vértice desse Estado tirânico, sustentando a esperança de que a degeneração futura poderia ser evitada. $\mathrm{O}$ caráter de suas intervençôes políticas foi bastante moldado por esse juízo equivocado, assim como por seu horror genuíno à perspectiva do derramamento de sangue entre concidadãos. É por isso que seus escritos sobre Genebra são marcados por um conservadorismo evidente que contrasta com o conteúdo revolucionário de suas doutrinas políticas ideais.

BERTRAM, Christopher. Rousseau and Geneva. Trans/Form/Ação, Marília, v. 38, p. 93110, 2015. Edição Especial.

\footnotetext{
ABSTRACT: Scholars have been sharply divided over the relevance of Genevan politics and history to Rousseau's political philosophy. In this article, I try to achieve a coherent view of Rousseau's engagement with Geneva, one that rejects the idea that Geneva is simply irrelevant to his core political doctrines, but that also rejects the view that essentially reads everything as a political intervention in
} 
Genevan politics. Neither of these views seem accurate. Rather, Geneva (as Rousseau thought of it) is a constant presence that informs his thinking in different ways. Rousseau was not so naive as to think that Geneva incarnated his principles, but neither did he see its true nature as a hereditary oligarchy. He judged it flawed but remediable, a judgement perhaps informed by a loathing of civil conflict, at least until Genevan reality collided with his illusions.

KEYWORDS: Rousseau. Geneva. Politics.

\section{REFERÊNCIAS}

BACHOFEN, B. La condition de la liberté: Rousseau, critique des raisons politiques. Paris: Payot, 2002.

DERATHÉ, R. Jean-Jacques Rousseau et la science politique de son temps. 2. ed. Paris: Vrin, 1995.

FRALIN, R. Rousseau and representation. New York: Columbia, 1978.

LAUNAY, M. Jean-Jacques Rousseau écrivain politique. Grenoble: CEL/ACER, 1971.

MILLER, J. Rousseau: dreamer of democracy. New Haven: Yale University Press, 1984.

ROSENBLATT, H. Rousseau and Geneva: from the first discourse to the Social Contract 1749-1762. Cambridge: Cambridge University Press, 1997.

ROUSSEAU, J.-J. CEuvres complètes. Paris: Gallimard, 2003. v. 3. . Euvres complètes. Paris: Gallimard, 1995. v. 5.

SILVESTRINI, G. Genève comme modèle dans la pensée politique de Rousseau. In: BERNARDI, B.; GUENARD, F.; SILVESTRINI, G. (Eds.). Religion, liberté, justice: un commentaire sur les Lettres écrites de la montagne de J.-J. Rousseau. Paris: Vrin, 2005. p. 211-240.

SPECTOR, C. Droit de représentation et pouvoir négatif: la 'garde de la liberté' dans la constitution genevoise. In: BERNARDI, B.; GUENARD, F.; SILVESTRINI, G. (Eds.). Religion, liberté, justice: un commentaire sur les Lettres écrites de la montagne de J.J. Rousseau. Paris: Vrin, 2005.

SPINK, J. S. Rousseau et Genève. Paris: Bovin, 1934.

Recebido / Received: 15/04/2015

Aprovado / Approved: 24/06/2015 
BERTRAM, C. 